be heard all along the coast the sound of the Bâroem, a great wooden gong, announcing to the islanders the departure of the "man-in-the-moon," who had taken up his abode for more than a year amongst them.

JOHN C. GALTON

\section{MICROSCOPIC EXAMINATIONS OF AIR}

$A$ WORK $^{*}$ of the greatest importance on the above subject has just been published in Calcutta by Mr. Douglas Cunningham. The conclusions which he has reached as the result of the experiment are so valuable that we deem it right to give them as great publicity as possible. The following is Mr. Cunningham's description of the aeroscope with which he made his experiments :-

The apparatus employed in obtaining specimens was a slightly modified form of that devised by Dr. Maddox. It consisted of three thin brass tubes, two of which slipped over the third central one and came into contact with the opposite side of a projecting rim on its circumference, This rim was formed by the margin of its diaphragm which divided the centre tube into two chambers. It was of sufficient thickness to allow of a spindle passing up through it. The latter terminated in a pointed extremity, which came in contact with the upper end of the bearing, and provided for the free rotation of the system of tubes. Round the margin of the diaphragm there was a set of perforations, to allow of the passage of air through it, and, on the centre of its anterior surface, there was a square plate of glass with a slightly projecting rim on its lower margin. The anterior of the two lateral tubes was provided with an expanded orifice, and contained a small, finely-pointed funnel in its interior; the pointed extremity opening immediately in front of the centre of the diaphragm-plate. The posterior tube was quite simple, and had a good-sized fish-tail vane fitted into a slit in its extremity.

The following are Mr. Cunningham's conclusions :-

The most important conclusions to be derived from all the proceding experiments regarding the dust contained in the atmosphere in the vicinity of Calcutta appear to be the following:-

$r$. The aeroscope affords a very convenient method for obtaining specimens really representing the nature of the true atmospheric dust.

2. Specimens of dust washed from exposed suraces cannot be regarded as fair inclices of the constituents of atmospheric dust, since they are liable to contain bodies which may have reached the surface otherwise than by means of the air, as wéll as others which are the result of local development.

3. Specimens collected by gravitation also fail to indi cate the vature and amount of organic cells contained in the atmosphere, as the heavier amozphous and inorganic constiruents of the dust are deposited in relative excess due to the method of collection.

4. Dew also fails to afford a good means of investigating the subject, as it is impossible to secure that all the bodies really present in a specimen of it should be collected into a sufficiently small space, and, moreover, because it is liable to accidental contaminations, and also affords a medium in which rapid growth and development are likely to take place.

5. Distinct infusorial animalcules, their germs or ova are almost entirely absent from atmospheric dust and even from many specimens of dust collected from exposed surfaces,

6 . The cercomonads and amcbæe appearing in certain specimens of pure rain-water appear to be zoospores developed from the mycelial filaments arising from common atmospheric spores.

Microscopic Examinations of Air," by D. Douglas Cunningham, M.P. Surgeon H.M. Indian Medical Service (Calcutta).
7. Distinct bacteria can hardly ever be detected among the constituents of atmospheric dust, but fine molecules of uncertain nature are almost always present in abundance ; they frequently appear in specimens of rain-water collected with all precautions to secure purity, and appear in many cases to arise from the mycelium developed from atmospheric spores.

8. Distinct bacteria are frequently to be found amongst the particles deposited from the moist air of sewers, though almost entirely absent as constituents of common atmospheric dust.

9. The addition of dry dust, which has been exposed to tropical heat, to putrescible fluids is followed by a rapid development of fungi and bacteria, although recognisable specimens of the latter are very rarely to be found in it while dry.

Io. Spores and other vegetable cells are constantly present in atmospheric dust, and usually occur in considerable numbers: the majority of them are living and capable of growth and development; the amount of them present in the air appears to be independent of conditions of velocity and direction of wind; and their numbers are not diminished by moisture.

II. No connection can be traced between the numbers of bacteria, spores, \&c., present in the air and the occurrence of diarrhœa, dysentery, cholera, ague, or dengue; nor between the presence or abundance of any special form. or forms of cells, and the prevalence of any of these diseases.

12. The amount of inorganic and amorphous particles and other débris suspended in the atmosphere is directly dependent on conditions of moisture and of velocity of wind.

If these results be compared with those obtained by other observers, and detailed in the first section of this report, it will be seen that they agree very closely with those of $\mathrm{M}$. Robin, only differing from them in indicating the presence of a somewhat larger number of spores than appeared in his observations. They differ almosî equally from those arrived at by Pouchet and Ehrenberg. It is somewhat difficult to understand how the former observer so constantly failed to detect the presence of spores in his experiments, but there is an apparent reason for Ehren. berg's observation of the predominance of animal forms in the atmosphere. His conclusions appear to have been almost entirely founded on the results of the examination of specimens of dust not directly obtained from the air, but from surfaces on which it had been previously deposited from the air, such as leaves, tufts of moss, \&c. Now, as has already been indicated, it is certainly quite unwarrantable to assume that all organisms found in such specimens existed as such in the air, or were even derived from the air in any way. All such surfaces are more or less liable to contact-inoculation; leaves and moss, for example, are liable to this through the agency of insects or birds. Moreover, with regard to many of the organisms detected in such situations, it must be recollected that there is no reason why they should not lave arrived there by means of active progression over the surface. When surfaces are wet with rain, there is no reason why Tardigrades, Rotifers, Anguillulæ, and many infusoria should not travel over them from one point to another. The journey accomplished at any one time may be small. and its progress soon arrested by defective moisture; but, unless they are deprived of vitality in the interval by desiccation, they are ready for a fresh start when favourable conditions are again presented to them.

It is hardly safe to venture on the vexed questions regarding the origin of bacteria, but it may, at all events, be stated that the results of the present experiments are certainly not opposed to the belief in the transmission of these organisms in some way or other by means of the atmosphere; for they were actually observed among the particles in moist air, the addition of dry dust to putre- 
scible fluids was followed by their rapid development, and they appeared in specimens of pure rain water.

Although these observations may not appear to encourage the hope of success in discovering the presence of atmospheric particles connected with the origin of disease, it must not be forgotten that they only refer to bodies distinguishable from one another whilst in the air, the possibility remaining that many of the finer molecules present in it are really of different natures, and may yet be distinguished from one another by means of their actions or developments. Many interesting questions are suggested in connection with the fact of the presence of such considerable numbers of living cells in the air. What becomes of them when drawn into the respiratory cavities of animals? Is their vitality destroyed, and, if so, how are they got rid of? Are they ever capable of undergoing any development within the organism, and do they then exert any prejudicial influence on the recipient? These and similar questions can only be answered by means of patient and extended experiment, but even such imperfect and superficial observations as the present will, I trust, serve a useful purpose in clearing away a few of the preliminary obstacles from the path of investigation.

\section{NOTES}

A Special General Meeting of the Linnean Society is to be held on Thursday, March 5, at 8 P. M., " to consider alterations in the Bye-laws of the Society ; "when it is expected a full explana. tion will be given of the reasons which induced the Council to make the alterations recently adopted by the Society, which met with such violent opposition from a small section of the Fellows. It is understood that Mr. Bentham, who has occupied the chair of the Linnean Society for the past eleven years, will not offer himself for re-election at the ensuing anniversary. The custom of the Society requires that the next president shall be a Zoologist, but students of both branches of Biology will be glad to learn that Prof. Allman has allowed himself to be nominated. Few naturalists would bring to the office a wider, and none a more sympathetic knowledge.

MR. HIND writes to the Times that he has received from Prof. Winnecke, Director of the Observatory at Strasburg, the following position of a comet discovered by him in the Constellation Vulpecula on the morning of Saturday last:--February 20 , at $17^{\mathrm{h}} 16^{\mathrm{m} 2} 40^{\mathrm{s}}$ menn time-right ascension, $20^{\mathrm{ln}} 35^{\mathrm{m}} 34^{\circ} 2^{\mathrm{s}}$; north declination, 26 deg. $0^{\mathrm{m}} 46^{\mathrm{s}}$. The diumal motion in right ascension is $9^{\mathrm{m}}$ increasing, and in declination $\mathrm{x}$ deg. $3 \mathrm{O}^{\mathrm{m}}$ towards the south.

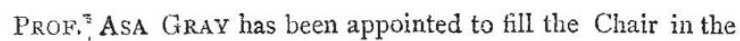
Board of Regents of the Smithsonian Institution, previously occupied by the late Prof. Agassiz.

The Rev. Dr. Thomas William Jex-Blake, Principal of Cheltenham College, has been elected Head-Master of Rugby School, in succession to Dr. Hayman.

A BARONETCY has been conferred upon Dr. George Burrows, F.R. S., President of the Royal College of Physicians.

WE would direct the attention of Palrontologists and others who are specially interested in the Cephalopoda, to a paper by M. Munier-Chalmas, in the Comptes Rendus for Dec. 29, 1873, which is translated in the current number of the Annals and Magazine of Natural History, in which, from a study of their earliest stages, the generally accepted systematic position of the Ammonitites and Goniatites is stated to be inaccurate, they being shown to be dibranciate decapoda allied to Spirula, and not tetrabranchiata at all.
There are two islands named St. Paul in the ocean : one close to the Equator was visited lately by the Challenger; the other, south of the Cape of Good Hope, is to be visited by a French expe. dition under Capt. Mouchez, for observing the forthcoming transit of Venus, as we stated in our last number. The identity of name has created a singular confusion. The French administration having decided that no naturalist was needed for St. Paul, the Challen. ger having explored the island a few months since, M. Mouchez had some trouble, it is said, to get the decision reversed by the authorities. Both islands, southern and northern, are almost of the same microscopical size and equally barren. They are of volcanic formation, with no trace of vegetable earth, and consequently of vegetation.

A TELEGRAM from Melboume, dated February I 7 , states that Colonel Egerton Warburton has reached Perth, in Western Australia, overland from Adelaide, having thus accomplished the object of the exploring expedition on which he left Tennant's Creek, north of Adelaide, in the centre of Australia, about twelve months ago. Colonel Warburton's exploxations embrace a portion of the interior of Western Australia hitherto unknown. The distance traversed is over 1,000 miles of longitude, the expedition having been conducted by means of camels, and was fitted out by the munificent liberality of the Hon. Thomas Elder, M. L. C., and Mr. W. W. Hughes. Another expedition under Mr. Gosse, conducted with horses at the expense of the Government of South Australia, has not been so successful. Mr. Gosse, amid many difficulties caused by want of water and the barren nature of the country through which he passed, managed to reach as far as E. long. $129^{\circ} 59^{\prime}$ in lat. $26^{\circ} 32^{\prime} \mathrm{S}$., the total distance traversed irrespective of numerous turnings and windings, being not less than 600 miles. His most notable discovery was made in lat. $25^{\circ} 21^{\prime}$, long. $131^{\circ} 14^{\prime}$, being a hill consisting of one solid rock (fine conglomerate) or huge natural monolith two miles long, one wide, and I, I00 feet high, with a spring coming from its centre; Mr. Gosse named it "Ayres Rock." Both expeditions are highly creditable to the enterprise of South Australia, which, as our readers know, has succeeded in carrying a line of telegraphy right across the country, from Port Augusta to Port Darwin.

The enterprise of the Australian Colonies is producing really valuable scientific results, as will be seen from the following telegram, dated Dec. 22, published in the Brisbanc Couricr; from Mr. G. Elphinstone Dalrymple, commander of the Queensland North-east Exploring Expedition :--"The coasts, harbours, inlets, navigable rivers, and creeks have been examined from latitude $18^{\circ} 15^{\prime}$ to $15^{\circ} \mathrm{I} 5^{\prime} \mathrm{S}$. The Bellenden Kerr mountain range has been successfully ascended, and foundto be a complete 'razor back' of granite. Palms were found on the summit; but although the botanical discoveries were interesting, they have not borne out all that was anticipated from them; 144 miles of soundings and 371 compass cross bearings have been taken in 19 navigable rivers and creeks of which the North and South Johnstone, the Mulgrave and Russell, drain the Bellenden Kerr range; the Mossman and Daintree drain the Arthur Palmer range inside the Schnapper Island. This range is nearly as lofty as the Bellenden Kerr, and is 25 miles in length. New rivers have been discovered penetrating a jungleclad country of thorougbly tropical character, covered with a new rich scil suitable for sugar and other tropical cultivation. The extent of this country is roughly estimated at, in the aggregate, half a million acres, thus at once placing Queensland on a par with other favoured tropical countries. Mir. Hill has collected 3,000 botanical specimens, roots, and blocks of timber; I30 shells of five genera and eight species; 42 specimen bags of soils. Mr. Johnstone has collected 30 specimens of interesting birds, insects, and reptiles; and I have obtained 93 geological specimens," 